\title{
Research on Present Situation, Problems and Solution of Coal Resource Tax Reform of Inner Mongolia
}

\section{Lin Tao}

School of Economics, Shanghai University, Shanghai, China

\section{Email address:}

757430336@qq.com

\section{To cite this article:}

Lin Tao. Research on Present Situation, Problems and Solution of Coal Resource Tax Reform of Inner Mongolia. Science Innovation. Vol. 5, No. 6, 2017, pp. 416-419. doi: 10.11648/j.si.20170506.25

Received: December 2, 2017; Accepted: December 21, 2017; Published: December 28, 2017

\begin{abstract}
China is a big country for coal production and consumption. Inner Mongolia, as an important province for coal supply, has the function of research representative. Due to overburden of coal enterprises under the existing coexistence of taxes and fees, imperfect tax bases make the interests of enterprises unequal. It is very common for coal enterprises to exchange short-term profits at the expense of wasting resources. The purpose of resource tax reform is based on the protection of resources, starting from the various elements of the resource tax system to achieve the comprehensive recycling of natural resources, and ultimately achieve energy-saving, emission reduction and sustainable development. Based on the discussion of Inner Mongolia coal resources tax policies and reforms, the paper clarifies the key directions of reform, puts forward some suggestions on how to carry out the reform in light of the original intention of reform, strengthen the policy of reducing costs and improving tax bases.
\end{abstract}

Keywords: Inner Mongolia, Coal, Resource Tax

\section{内蒙古煤炭资源税改革现状、问题与对策研究}

陶林

经济学院, 上海大学, 上海, 中国

邮箱

757430336@qq.com

摘要：中国是煤炭生产消费大国，内蒙古作为煤炭供应重要省，具有研究代表性的功能。由于煤炭企业在原有税费共 存机制下负担过重，不完善的计税依据使得企业间利益不均，煤炭企业以损失浪费资源为代价来换取近期利益的现象 十分普遍。资源税改革目的是以保护资源为依据，从资源税制的各要素入手，实现自然资源的综合回收利用，最终达 到节能减排, 可持续发展。本文通过对内蒙古煤炭资源税政策、改革等问题的讨论, 明确改革的重点方向, 加强和落 实清费立税、改进计税依据的政策。

关键词: 内蒙古, 煤炭, 资源税

\section{1. 引言}

煤炭是中国工业部门燃料动力的主要来源。内蒙古 是中国能源和矿产的富集区, 其资源储量优势明显, 在
这样的煤炭资源富集地区的而言, 经济发展与煤炭资源 浪费、环境污染之间的矛盾十分突出。本文通过对具有 代表性的内蒙古进行分析并为完善改革提出意见。煤炭 资源税改革必然带来多方面的影响, 税率变化和取消收 
费必然面临实践检验, 即能否达到并如何达到体现资源 有偿性和调节级差收入的功能。对于内蒙古这样的煤炭 资源富集地区而言, 经济发展与煤炭资源浪费、生态环 境污染严重之间的矛盾尤为突出。政策的最终目标是建 立立“政府部门充分发挥其职能、立法机关制定切合本地 实际的法律法规、企业依法自律、社会舆论积极参与、 公众积极关注” 的五位一体解决内蒙古资源税问题的新模 式。

但是这种模式的建立是要符合经济、社会各方面的 发展与进步的进程, 本论文结合内蒙古情况从理论角度 探讨了解决煤炭资源税问题的方法，而在实践角度仍然 有待政策制定者结合政策改革效果进行修正。同时在政 策落实执行方面的具体情况有待进一步考察。本文在阐 述资源税以及煤炭资源税相关理论的基础上, 分析中国 煤炭资源税现状以及当中存在的一些问题, 分析过程中 以我国的内蒙古为例,同时借鉴国外煤炭资源税制设计的 经验, 在此基础上提出对我国煤炭资源税改革的政策建 议。

\section{2. 内蒙古煤炭资源税现状}

资源税是一种地方税种, 是地方财政收入的一项来 源，但是资源税对内蒙古这样资源富集地区的财政贡献 度却较低。如表1所示1994-2012年资源税收入占内蒙古 税收收入的比重平均为 $3.77 \%$, 占内蒙古财政收入的比重 平均为 $2.14 \%$, 占内蒙古财政支出的比重平均为 $1.25 \%$ 。 所以内蒙古作为中国目前第一大产煤省的地位来看, 部 分地区煤炭资源税税率偏低, 资源税收入规模较小, 与 对能源要素投资的增长方式不协调, 而且收入不能满足 本地区环保产业维持功能，不能支撑经济社会的可持续 发展。内蒙古煤炭资源税收入占税收总收入常年在 $3 \%$ 到 $5 \%$, 作为对煤炭资源保护而征收的煤炭资源税收入占财 政支出的比重较少, 常年不到 $1.5 \%$ 甚至更少, 体现出了 内蒙古煤炭资源税在征收后的用途没有完全发挥作用,
财政收入对环保部门的支持没有落到实处, 煤炭资源税 的作用机制产生了非效率。2013年, 内蒙古税收总量实 现收入 10949184 元, 其中资源税收入为706427元, 占比 重为 $6.45 \%$ 。与其他省份相比, 内蒙古资源税比重明显应 该较高, 即作为一种调节税, 煤炭资源税在内蒙古发挥 着更强的作用。就占税收收入比重而言, 内蒙古煤炭资 源税占税收总量的比重极少, 内蒙古近年来的煤炭资源 税增长极为缓慢, 说明煤炭资源税在内蒙古还有很大的 立税空间, 即为煤炭资源税税率上升以改进资源配置机 制提供了可能。

\section{3. 内蒙古煤炭资源税改革存在的问题及分析}

\section{1. 重复收费破坏资源配置机制}

对煤炭资源税政策落实不到位, 大量重复收费破坏 了税收对资源配置的调整机制。第一, 政出多门、重复 征收, 导致煤炭企业税费负担越来越重。第二, 煤炭增 值税税负重。2012年到2013年，中国规模以上煤炭企业 增值税综合税率为 $8 \%$, 是中国工业企业平均水平的两倍 多, 煤炭企业实际增值税税率仅低于石油和天然气开采 业与烟草业。第三, 多数产煤省 (自治区、直辖市) 征 收价格调节基金, 在一定程度上增加了企业的生产经营 压力。

\section{2. 从量计征不能适应现状}

煤炭资源税从量计征不能适应煤炭市场萧条的现状， 挤压了大量中小煤炭企业生存空间，不利于形成煤炭市场 价格形成机制。根据最新内蒙古监测数据显示：2015年一 季度, 受经济增速下滑及行业供应过剩影响, 内蒙古煤炭 价格延续两年来的下降走势, 价格进一步下滑。该区动力 煤平均坑口价格为 142.12 元/吨, 较2014年四季度环比下跌 $0.38 \%$, 较 2014 年一季度同比下跌近一成, 为 $9.22 \%$ 。

表1 内蒙古2006年-2013年全区地方税分税种完成情况。

\begin{tabular}{|c|c|c|c|c|}
\hline 年份 & 税收收入合计 & 资源税 & 资源税比重 & 动力煤平均价格 \\
\hline 2006 & 2036837 & 127752 & 6.27 & - \\
\hline 2007 & 2834764 & 166774 & 5.88 & - \\
\hline 2008 & 3770495 & 220577 & 5.85 & - \\
\hline 2010 & 6151952 & 368177 & 5.98 & 370 \\
\hline 2011 & 8278063 & 568115 & 6.86 & 360 \\
\hline 2012 & 10151435 & 681046 & 6.71 & 290 \\
\hline 2013 & 10949184 & 706427 & 6.45 & 280 \\
\hline 2014 & - & - & - & 250 \\
\hline
\end{tabular}

从表1数据可以看出, 内蒙古煤炭煤炭资源税收入 总体逐渐增加, 而随着煤炭市场逐渐萧条, 煤炭价格却 总体呈下降趋势。说明了煤炭企业尤其是中小煤炭企业 正面临着前所未有的困境。在生产规模上的劣势使得中 小煤炭企业不能十分灵活的调整产量和产品, 可能促使 中小煤炭企业进行短期过度开发和恶心价格竞争, 不利 于市场价格机制的形成。另一方面, 改革前资源税对区 域间财政能力的调节作用非常有限, 这主要是由于资源 税制自身设计存在的问题，使资源富集地区从资源开采
上取得的收入极其有限。资源的收益大都通过价格机制 传导给了东部地区, 实质上是东部地区用过低的价格买 到了煤炭, 进一步扩大了东西部之间经济社会发展的差 距, 煤炭资源的这种不合理的流动也政府行为提供了依 据。

综上所述, 从量计征不能合理反映市场价格变化。当 价格上升时, 从量计征会造成煤炭企业单位产量的税收负 担降低, 导致煤炭企业过度开采, 而当价格下降时, 从量 
计征会导致煤炭企业单位产量的税收负担提高, 导致中小 煤炭企业负担过重。

\section{3. 计税依据不够合理}

原煤与洗选煤具有不同的环保属性，对洗选煤计税 采取同原煤无区别对待导致企业追求短期经济利润的同
时损害了自然环境和可持续发展, 不利于推动内蒙古经 济结构调整和经济发展方式转变。内蒙古煤炭开采存在 的环境问题主要是：煤炭开采方法原始，对煤矿资源利 用度低。这就导致了煤炭储量最丰富的内蒙古成为了我 国煤炭产业能耗最高的地区。

表2 2007-2012年内蒙古单位能耗(吨标准煤 / 万元)情况表。

\begin{tabular}{lllllll}
\hline 指标/年份 & $\mathbf{2 0 0 7}$ & $\mathbf{2 0 0 8}$ & $\mathbf{2 0 0 9}$ & $\mathbf{2 0 1 0}$ & $\mathbf{2 0 1 1}$ & $\mathbf{2 0 1 2}$ \\
\hline 全国平均值 & 1.160 & 1.102 & 1.077 & 1.034 & 0.793 & 0.696 \\
当年最低值 & 0.714 & 0.662 & 0.606 & 0.582 & 0.459 & 0.441 \\
& (北京) & (北京) & (北京) & (北京) & (北京) & (北京) \\
当年最高值 & 3.954 & 3.685 & 3.454 & 3.308 & 2.279 & 2.209 \\
东部平均值 & (宁夏) & (宁夏) & (宁夏) & (宁夏) & (宁夏) & (宁夏) \\
中部平均值 & 1.044 & 0.906 & 0.924 & 0.892 & 0.739 & 0.608 \\
西部平均值 & 1.468 & 1.381 & 1.322 & 1.227 & 0.979 & 0.732 \\
内蒙古自治区 & 2.131 & 2.021 & 1.867 & 1.737 & 1.356 & 1.145 \\
\hline
\end{tabular}

如表2所示, 内蒙古的单位GDP能耗较高, 高于全国 平均水平, 也高于东部、中部、西部三个区域的平均水 平。这种以能耗消费为核心动力的经济增长模式, 致使 自然灾害频发, 自然灾害和地质灾害直接损失加大, 治 理环境总投资额持续需要增加, 从经济效率角度来看, 不符合最优资源配置。

综上所述，以上问题存在的主要原因是中国旧的资 源税体系不能很好的符合新时代和市场的需要, 在“无偿 性”制度和“有偿开采”原则这两个问题上存在矛盾。新资 源税体系应该是对旧体系的改革完善, 其征收目的为调 节级差收益, 它会带来新的问题, 即普遍征收而并不对 各个企业的盈利情况加以区分, 即使企业发生了亏损也 同样需要缴纳资源税, 这是不合理的, 对企业的发展不 利。所以, 国家煤炭资源税改革政策的出台符合政府财 政工具使用的目标，即政府应促进节能环保和高效率的 市场价格机制的形成。

\section{4. 锡林郭勒盟和鄂尔多斯的实例分析}

\section{1. 煤炭产业萧条背景下的改革一一以内蒙古锡林郭勒 盟为例}

锡林郭勒盟煤炭资源丰富, 含煤面积约占全盟面积 的 $4.5 \%$, 煤炭资源分布在全盟 11 个旗县市, 现已探明 和预测煤炭资源储量为 1882.8 亿t, 可采总储量 722 亿t。 2014年1-3季度税收收入中，煤炭采矿行业整体实现税收 9.32 亿元。炭行业收入占全部税收的 $24.84 \%$, 较上年同 期下降7.88 个百分点。可以看出, 近年来中国进入能源 转型期, 煤炭市场需求下降, 煤炭价格持续低迷下跌, 从统计数据可以看出锡林郭勒盟煤炭行业税收占该地区 税收收入比重较大, 是举足轻重的支柱产业。而2014年 煤炭交易量已呈现下降趋势。

因此, 在萧条的内蒙古煤炭市场进行改革需要更加 谨慎。在可以预期的未来几十年, 中国整体能源需求结
构不会发生彻底的质变, 如果这个效应不能得到体现, 可以预见, 在煤炭行业不景气的当前趋势和能源转型的 大背景下, 煤炭资源税改革的效果将要打折扣。过高的 税率会推高整体能源成本, 在税负转嫁的情况下, 由消 费者和生产者共同负担; 过低的税率起不到调节煤炭资 源级差收入的目的, 也不利于产业结构的调整。通过煤 炭资源税这一工具进行调节, 既要符合优化资源配置的 改革方向, 又要照顾到现阶段煤炭行业的低迷, 即应该 突出落实为煤炭企业减负这一效应。

\section{2. 改革可能对内蒙古中小企业形成额外成本一一以内 蒙古鄂尔多斯为例}

2011年鄂尔多斯市对煤炭开采企业征收的各种费用 合计 11.72 元/吨, 2011年山西省对煤炭开采企业征收的 各种费用合计 21.025 元/吨。2014年一季度, 鄂尔多斯市 五大重点行业中煤炭、煤制油、金融三行业同比减收; 化工、电力同比增收。五大重点行业共完成税收 34.01 亿 元, 占全部税收的 $68.49 \%$, 同比减收 24.57 亿元。其中煤 炭行业（包括采掘、洗选和批发运销）入库23.71亿元, 较上年同期减收 24.08 亿元, 是减收的主要因素。

通过两地区的费用对比, 以及鄂尔多斯煤炭减产的 事实表明，资源税提升后也将导致一些负面影响。此次 改革中, 内蒙古煤炭资源税率在中国是最高, 与山西相 比也高出一些。近几年内蒙古取代山西成为了中国第一 产煤大省, 不仅是因为山西通过煤炭行业整合使得省内 煤炭产量减少, 而且是因为内蒙古煤炭行业行政性税费 比山西少, 这一点可以在数据中得知。首先, 现行主要 减负政策“清费立税”有待完善。取消收费的监督机制有 待完善, 这是内蒙古煤炭资源税改革的运行基础。而这 对于复杂的社会资源流动来说是不够的, 其效应是难以 较好监测的。因为企业可能将税收成本的上升转嫁到消 费者头上，因此相关配套政策的制定必须考虑规范煤炭 企业市场行为。 


\section{5. 建议与结论}

\section{1. 针对税费共存问题的对策}

首先, 理清涉税各方利益关系。煤炭资源税率通常在 较低时才能为企业减负, 但税率太低不符合中国煤炭资源 税改初衰。煤炭资源税改革最重要的基础是要明确各方利 益，权衡社会福利制定政策。本文认为，应当优化资源配 置, 逐步消除乱收费现象。落实到行动上应该是加强监督 部门权利的建设和监督部门运行的独立性。其次, 建立完 善的监督机制和相关法律。煤炭资源税改革的可行是建立 在对不合理收费的坚决取缔的基础上的，针对煤炭企业可 能因市场应当建立完善的监督机制，简化监督机制的运行 环节，将发现乱收费到取缔该收费的中间环节最大简化， 对擅自设立收费项目、自行提高收费标准等乱收费行为, 依法从严查处, 确保煤炭资源税改革平稳实施。

\section{2. 针对从量计征带来的问题的对策}

各地区根据具体情况设置浮动税率。煤炭资源税改 革的原理可以部分地理解为用合理的税率上升来代替以 往不规范的各项收费。如煤炭资源税实行“从价计征”, 为了解决税率可根据不同地区不同煤炭发热量和销售价 格定一个上下浮动的税率。

\section{3. 针对计税依据不科学的问题的对策}

加强区分不同类型煤炭税差别征收、不同开采阶段 征收的落实。不同的种类的煤炭资源储量不同、开采条 件不同，因此价格也不同。因此，对焦煤、动力煤、精 煤、原煤等从品种和用途角度分类的煤炭资源采用不同 的税率和计税公式。此外, 对不同开采阶段的征收也可 考虑差别化。可以借鉴国外的经验, 将开采新煤矿的阶 段的征收税率降低, 从而鼓励内蒙古煤炭产业在开采过 程中注重对现有煤矿的合理开采，而不是为了短期的经 济利润对现有煤矿采用过度开采的方式, 从而达到保护 内蒙古煤炭资源产业的可持续发展。

\section{4. 针对萧条市场中的可持续发展问题的对策}

制定煤炭企业规模指标和效率指标。煤炭产业作为 产业结构中的衰退产业, 在具体的配套政策上, 应暂时 用硬性规模和产能标准将落后企业退出行业或兼并至高 效率企业进行资源优化重组, 对于退出的行业可以给予 重新进入的政策优惠, 对重组的新企业可以对勘探新矿 制定更多优惠政策。在为煤炭企业减负的同时可以制定 行业进入规制, 如对煤炭企业的规模和节能指数制定指 标, 落后的中小煤炭企业将不得不退出市场, 避免资源 浪费和恶性价格竞争的低效率, 让煤炭行业减负的成果
真正落实到做出贡献的煤炭企业手中, 即最好地满足市 场需求的厂商获得最高的报酬。

综上所述, 内蒙古在清费立税、改进计税依据的资源 税改革进程中, 应该采取相关政策来辅助煤炭资源税, 从 而使煤炭资源保护不仅是从政府角度通过税收调整资源分 配，使得企业在财务环节拥有更多的运行空间，生产建立 在可持续发展的基础上进行。部分地区的税负略高于改革 前但低于最高价格时的税负, 短期内初步从企业负担角度 来看改革已初见成效, 即保护了中小企业的利益。然而, 能否达到保护资源和调节收入的功能难以在短期内完全验 证, 即改革效果需要长期验证。若政策执行不足, 很难证 明在长期内市场因素价格变动等因素下能持续发挥作用。 因此必须保持对改革进行持续观察与完善。

\section{参考文献}

[1] 刘晔. 资源税改革的效应分析与政策建议 [J]. 税务研究, 2010,05:7

[2] 赵峰. 关于对锡林郭勒盟煤炭资源税有关问题的思考 [J]. 内 蒙古科技与经济，2010,01:7-8

[3] 于光军. 煤炭资源税改革对煤炭产业及内蒙古煤炭主产区 的影响分析 [J]. 北方经济, 2014,06:6

[4] 张玉龙. 煤炭资源税改革探析[J]. 煤炭经济研究, 2012,2:58

[5] 李英伟. 对我国煤炭资源税费体制改革的新构想 [J]. 税务与 经济, 2013,02:16

[6] 李恒炜. 矿产资源有偿使用的国际经验借鉴与税费改革走 势[J]. 改革，2013,07:4-6

[7] 李波. 煤炭资源税改革目标实现的困境与对策 [J]. 中国人口 资源与环境, 2013,01:5

[8] 施文泼. 清费立税: 进一步深化矿产资源税费制度改革[J]. 涉外税务, 2013,03:7-10

[9] 曾庆宝. 我国煤炭资源税从价计征的局限性研究一基于征 税效果和效率的预评价[J]. 煤炭经济研究, 2012,08:17

[10] 王文平. 我国煤炭资源税费合理性分析[J]. 2008,01:12-15

[11] 高文静. 煤炭资源税费改革对工业“三废”排放的影响--基于 山西的实证研究 [J]. 生态经济, 2011,03:20-24

[12] 李俊英. 内蒙古煤炭资源税改革研究 [J]. 北方经济, 2014,06:15 